New Approaches to Ezra Pound 



\section{New Approaches to}

EZRA POUND

$A$ Co-ordinated Investigation of

Pound's Poetry and Ideas

\section{EDITED WITH AN INTRODUCTION BY}

\section{EVA HESSE}

Berkeley and Los Angeles: 1969 
University of California Press

Berkeley and Los Angeles, California

(C) this collection Faber \& Faber Ltd 1969

Library of Congress Catalog Card No. 76-78928

Printed in Great Britain 